\title{
European Recommendations on Robotics and Related Issues in Education in Different Countries
}

\author{
Michele Domenico Todino, Giuseppe De Simone, Simon Kidiamboko, \\ and Stefano Di Tore
}

\begin{abstract}
This short paper describes the preliminary phase in an innovative line of research comparing educational robotics in Italy and other countries, from the perspective of media education, and based on the European Parliament recommendations to the Commission on civil law rules on robotics. More specifically, all decision processes that affect digital citizenship should have the support of children and teenagers. For these reasons, this paper looks at the work of a group of Italian high school students in the fifth year of upper secondary school, who formulated a SWOT analysis to highlight their attitudes to robotics issues in relation to the European Union recommendations. This research started in 2018 and will be repeated this academic year with Italian and Congolese students-from the Institut Supérieur des Techniques Appliquées — with a qualitative analysis to establish student attitudes to robotics issues. Qualitative analysis was selected because the SWOT analysis is already divided into information categories, revealing a variety of concepts that are grouped together from the collected data. These results will be compared with any obtained in future years in Italy and other countries, to find further potential patterns.
\end{abstract}

Keywords EU recommendations $\cdot$ Robotics $\cdot$ Artificial intelligence $\cdot$ SWOT analysis on robotics $\cdot$ Media education

\footnotetext{
M. D. Todino $(\varangle) \cdot$ G. De Simone $\cdot$ S. Di Tore

University of Salerno, Fisciano, Italy

e-mail: mtodino@unisa.it

G. De Simone

e-mail: gdesimone@unisa.it

S. Di Tore

e-mail: sditore@unisa.it

S. Kidiamboko

Institut Supérieur Des Techniques Appliquées, Kinshasa, Congo

e-mail: simon.kidiamboko@ista.ac.cd
} 


\section{Introduction}

This paper compares ICT education in robotics and artificial intelligence (AI) [1] in Italy and the Democratic Republic of Congo (DRC) purely in terms of media education [2]. It refers to other studies to describe the history [3], the service to citizens [4], the risks and myths [5] and the current and future levels of development in robotics and AI [6]. The starting point for this research is the recommendations to the European Commission on civil law rules on robotics [7] written in 2017 by the European Parliament's Committee on Legal Affairs. The focus of the recommendations is digital citizenship, which is needed for self-actualization, employability, social inclusion and responsibility. According to article 5 of the law, students should analyze, compare and critically evaluate data information, which today often comes from robots and machines that use artificial intelligence; students should identify appropriate forms of digital communication, robotics are a form of media; students should "be able to avoid risks using digital technologies for health and threats to one's physical and psychological well-being," and here it is important to know the risks linked to robots [8]. Thus, this law encouraged educational research to improve certain criteria for implementing these topics alongside students, teachers, families and industry experts. More specifically, all decision processes that affect digital citizenship should have the support of children and teenagers.

\section{An Explorative Student SWOT Analysis on Robotics}

For the above reasons, this paper has the following process: an educator in media studies in a fifth-year class (Table 1) at Istituto Statale Caravaggio upper secondary school in San Gennaro Vesuviano, Italy (www.iscaravaggio.gov.it) invited the students to prepare a SWOT analysis on the European recommendations on robotics. This would involve compiling a list of points highlighting their opinions and beliefs on robotics, based on their real-life experience. These ideas were then classified as strengths, weaknesses, opportunities and threats, and presented in table form along with direct quotes from the European document. Table 2 shows the results of the survey conducted in the 2018/19 academic year. The survey will be repeated in 2019/20 on new sets of students in two countries: (1) approximately 50 students in two fifth-year classes of the same upper secondary school in Italy; (2) approximately 75 students in their first year of university at Institut Supérieur des Techniques Appliquées in DRC; the research will take place in the fall semester to ensure the

Table 1 Details of fifth-year upper secondary class $(2018 / 19)$

\begin{tabular}{l|l|l}
\hline Year of birth & Male & Girls \\
\hline 2000 & 13 & 2 \\
\hline 2001 & 1 & 3 \\
\hline
\end{tabular}


Table 2 Results of the SWOT analysis of Italian upper secondary school students (2018-19)

\begin{tabular}{l|l}
\hline Dimension & Text quoted from the EU recommendations to summarize the students' opinions \\
\hline Strengths & $\begin{array}{l}\text { "automation of jobs has the potential to liberate people from manual monotone } \\
\text { labour allowing them to shift direction towards more creative and meaningful } \\
\text { tasks" (introduction, point J) [7] }\end{array}$ \\
\hline Weaknesses & $\begin{array}{l}\text { "whereas in the face of increasing divisions in society, with a shrinking middle } \\
\text { class, it is important to bear in mind that developing robotics may lead to a high } \\
\text { concentration of wealth and influence in the hands of a minority" (introduction, } \\
\text { point K) [7] }\end{array}$ \\
\hline Threats & $\begin{array}{l}\text { Build "homecare and healthcare robots" (preamble to the code of ethical conduct } \\
\text { for robotics engineers) [7] }\end{array}$ \\
$\begin{array}{l}\text { "Considers that, as is the case with the insurance of motor vehicles, such an } \\
\text { insurance system could be supplemented by a fund in order to ensure that } \\
\text { reparation can be made for damage in cases where no insurance cover exists; } \\
\text { calls on the insurance industry to develop new products and types of offers that } \\
\text { are in line with the advances in robotics" (point 58) [7] and "establishing a } \\
\text { compulsory insurance scheme where relevant and necessary for specific } \\
\text { categories of robots whereby, similarly to what already happens with cars, } \\
\text { producers, or owners of robots would be required to take out insurance cover for } \\
\text { the damage potentially caused by their robots" (point 59-a) [7] besides "creating } \\
\text { a specific legal status for robots in the long run, so that at least the most } \\
\text { sophisticated autonomous robots could be established as having the status of } \\
\text { electronic persons responsible for making good any damage they may cause, and } \\
\text { possibly applying electronic personality to cases where robots make autonomous } \\
\text { decisions or otherwise interact with third parties independently" (point 59-f) [7] }\end{array}$ \\
\hline
\end{tabular}

students are of comparable age. The Italian students were chosen for the research because there was open access to the school for their participation; the same is true for the students in Kinshasa. Researchers expect to find similarities between the Italian and Congolese SWOT analyses. Finally, this process aims to follow best practices in inclusive education [9], to find a proven approach to robotics, from a media education perspective, and share this approach with other countries.

As described above, a media educator first read the EU recommendations to the students. The students were then invited to state their opinions of them in terms of their strengths, weaknesses, opportunities and threats, for the purposes of the SWOT analysis. Classmates decided to confirm or reject each idea as a strength, weakness, opportunity or threat, or revise the opinion for inclusion in another section of the SWOT analysis. The reading of the recommendations and the students' work to produce the final version of the shared SWOT analysis with the quoted text took approximately eight hours.

In summary, Table 2 shows that students are wary of the threats of robotics, but they hope it will improve homecare, healthcare and liberate them from manual jobs, although this may not decrease divisions in society. These data will be compared with any obtained in future years in Italy and other countries, to find potential patterns. 


\section{Italy and DR Congo: A Predictive Comparison}

Every year, the education system in DRC produces large numbers of graduates, who, unfortunately, usually struggle to get work. As a result, some of them try to start their own businesses to avoid unemployment. For example, one Congolese startup has developed "Taxmwinda," a platform for paying taxes. This platform uses a white-box approach [10] and includes four subsets: a database, an SMS handler, and a mobile payment layer. Another Congolese startup "AgroMwinda" launched a web platform to support small farmers and local organizations, by providing innovative solutions and attractive services that make them more visible to customers. Finally, a Congolese women's technology startup led by Thérèse Izay, an engineer from Institut Supérieur des Techniques Appliquées, designed a robot that controls traffic lights, and will replace some traffic police on the street. The government will partly fund the production of more robots. Interest in robotics in DRC has led to the idea of an international collaboration to repeat the research previously done in Italy, as described above, at the Institut Supérieur des Techniques Appliquées in the DRC's capital, Kinshasa. To start this collaboration, the Italian researchers asked their Congolese colleagues a number of questions (Table 3) that can be generalized for other international institutions that might decide to join this research.

\section{Conclusion}

In conclusion, in the 2019-20 academic year, the Italian and Congolese researchers will work in parallel, gathering new data from a total of 50 Italian students (who will be added to those involved in 2018-19) and 70 Congolese students. These data will undergo a qualitative analysis because the SWOT analysis is already divided into information categories, revealing a variety of concepts that are grouped together from the collected data. The data will also be analyzed on the basis of several research questions: (1) Do Italians and Congolese have common parameters for evaluating the strengths, weaknesses, opportunities and threats of robotics? (2) Are there any cultural factors that might align the previous considerations? Obviously, the limited number of students involved in this research means that the resulting data are not analyzed quantitatively. The aim of the study is to introduce the topic of media education in robotics, which needs to be explored in more depth. This paper simply describes the activities of the researchers and shows the preliminary results. It further aims to present a new perspective for the introduction of robotics to fifth-year upper secondary school classes, as part of media education, and shows an experience that can help advance theoretical knowledge in educational robotics, and its effect on contemporary society, which students should be learning at school. 
Table 3 Answers provided by the researchers at the Institut Supérieur des Techniques Appliquées (ISTA). Please note that the Congolese research group is aware of other research published by their Italian colleagues

\begin{tabular}{|c|c|}
\hline Question & Answer \\
\hline $\begin{array}{l}\text { (1) Is robotics regulated by laws in your } \\
\text { country? }\end{array}$ & $\begin{array}{l}\text { "No, till now there is no regulation about } \\
\text { robotics in DR Congo even though robotics is } \\
\text { being used in daily life in our country" }\end{array}$ \\
\hline $\begin{array}{l}\text { (2) Do high schools have robotics lessons in } \\
\text { your country? }\end{array}$ & $\begin{array}{l}\text { "No, robotics is studied, but this subject starts } \\
\text { at university. Besides, white-box approaches in } \\
\text { robotics could be useful in DR Congo, because } \\
\text { it will help students to better understand } \\
\text { complex systems based on artificial } \\
\text { intelligence software" }\end{array}$ \\
\hline $\begin{array}{l}\text { (3) Would it be useful to read the European } \\
\text { recommendations in high schools in your } \\
\text { country? }\end{array}$ & $\begin{array}{l}\text { "Yes, it is important to publish and share the } \\
\text { European Parliament recommendations on } \\
\text { robotics in Congolese universities, and discuss } \\
\text { them, like it has been done in Italy so that } \\
\text { students can be aware of them" }\end{array}$ \\
\hline $\begin{array}{l}\text { (4) How will you plan this research in your } \\
\text { country? }\end{array}$ & $\begin{array}{l}\text { We will be discussing the European Parliament } \\
\text { recommendations on robotics with } 75 \text { students } \\
\text { in the first year of the computer science and } \\
\text { electrical engineering course, helped by } \\
\text { researchers, during the academic year } \\
\text { (2019/2020) in the Mechatronic Lab at the } \\
\text { ISTA, Kinshasa. This project is important due } \\
\text { to the fact that applications based on artificial } \\
\text { intelligence (robotics and expert systems) are } \\
\text { popular trends; thus, people who are not in } \\
\text { touch need to start this contact to improve their } \\
\text { technological skills and have more digital } \\
\text { citizenship, also in DR Congo. Even though, } \\
\text { there is no regulation, for the time being, of } \\
\text { artificial intelligence in DR Congo, everyone } \\
\text { tends to apply it when needed. At this point, } \\
\text { ISTA has created an Artificial Intelligence } \\
\text { work group in DR Congo (IARDC) as its } \\
\text { contribution to push this field forward in the } \\
\text { country }\end{array}$ \\
\hline
\end{tabular}

\section{References}

1. Russell, S.J.A., Norvig, S.J.: Artificial Intelligence: A Modern Approach. Prentice-Hall, Chicago (2003)

2. Rivoltella, P.C.: Media education. In: Rivoltella, P.C., Rossi, P.G. (eds.) Tecnologie per l'educazione. Pearson, Milan (2019)

3. Stanford University Report. One hundred year study on artificial intelligence. Report of the 2015 study panel (September 2016)

4. GID, The agency for digital Italy. White paper on artificial intelligence at the service of citizens. Version 1.0 March. https://ia.italia.it/assets/whitepaper.pdf (2019). Last accessed 12 September 2019 
5. IBM. Demystifying artificial intelligence in risk and compliance. https://www.ibm.com/dow nloads/cas/DLJ28XP7 (2019). Last accessed 12 September 2019

6. IMCO Committee, European Parliament. State of the art and future of artificial intelligence. Department for Economic, Scientific and Quality of Life Policies Directorate-General for Internal Policies Author: Dr. Aleksandra Przegalinska PE 631.051-February (2019)

7. Delvaux, M., Mayer, G., Boni, M.: With recommendations to the commission on civil law rules on robotics (2015/2103(INL)). http://www.europarl.europa.eu/sides/getDoc.do?pub $\mathrm{Ref}=-/ / \mathrm{EP} / / \mathrm{TEXT}+\mathrm{REPORT}+\mathrm{A} 8-2017-0005+0+\mathrm{DOC}+\mathrm{XML}+\mathrm{V} 0 / / \mathrm{EN}$ (2019). Last accessed 12 September 2019

8. European Union. DigComp 2.0: the digital competence framework for citizens. https:// publications.jrc.ec.europa.eu/repository/bitstream/JRC101254/jrc101254_digcomp\%202.0\% 20 the $\% 20$ digital $\% 20$ competence $\% 20$ framework $\% 20$ for $\% 20$ citizens. $\% 20$ update $\% 20$ phase $\%$ 201.pdf (2016)

9. Schwab, S.: Attitudes towards inclusive schooling. A Study on Students', Teachers' and Parents' Attitudes, p. 117. Waxmann, Münster (2018)

10. Todino, M.D.: Simplexity to orient media education practices. Aracne, Rome (2019)

Open Access This chapter is licensed under the terms of the Creative Commons Attribution 4.0 International License (http://creativecommons.org/licenses/by/4.0/), which permits use, sharing, adaptation, distribution and reproduction in any medium or format, as long as you give appropriate credit to the original author(s) and the source, provide a link to the Creative Commons license and indicate if changes were made.

The images or other third party material in this chapter are included in the chapter's Creative Commons license, unless indicated otherwise in a credit line to the material. If material is not included in the chapter's Creative Commons license and your intended use is not permitted by statutory regulation or exceeds the permitted use, you will need to obtain permission directly from the copyright holder. 